\title{
A review on the antibacterial potential of cantabiline-based derivatives
}

\author{
Noora Thamer Abdulaziz, Yasser Fakri Mustafa* \\ Pharmaceutical Chemistry Department, College of Pharmacy, Mosul University, \\ Nineveh, Iraq. \\ *Corresponding author: Dr.yassermustafa@uomosul.edu.iq
}

\section{ABSTRACT}

Received Accepted

Objective: The target of this review study is to

30.11.2020 20.12.2020

highlight the importance of cantabiline and its derived compound as antibacterial agents. Also, to take into consideration the characteristic structural features that can enhance the capability of these compounds to fight pathogenic bacteria.

Methods: The recently available reports concerning the antibacterial activity of cantabiline-derived compounds have been reviewed efficiently. The outcomes of these reports have been also analyzed to detect the proper substituents that can enhance the target activity.

Results: The hand-availability of antibacterial agents, as well as their inadvisable utilization, resulted in a mounting health problem named multidrug resistant bacterial strains. To handle this emerging issue, the design and synthesis of agents with a powerful ability to fight such bacterial strains is becoming a pressing need.

Conclusion: This review study has concluded that cantabiline and its derived compounds may represent hopeful antibacterial agents. Also, they can address several mechanisms acquired by bacteria for resisting the currently-available antibacterial agents.

Keywords: Coumarin, pathogenic bacteria, cantabiline, antibacterial activity. 
الغاية من الدراسة: ان الهذف من هذه الدراسة الاستعر اضية هو تسليط الضوء على أهمية ألهاء الكانتابلين

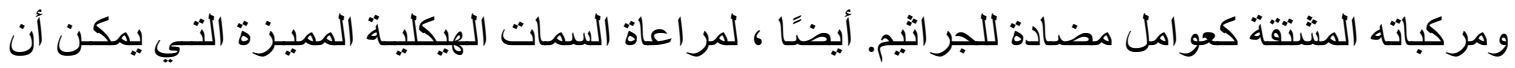

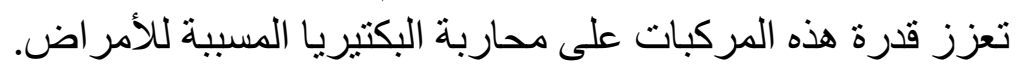

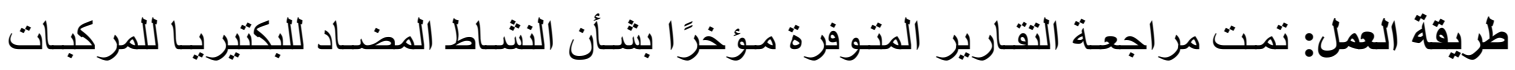

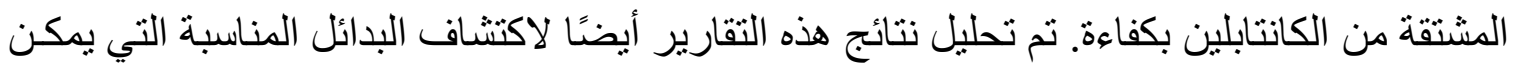
أن تعزز النشاط المستهدف.

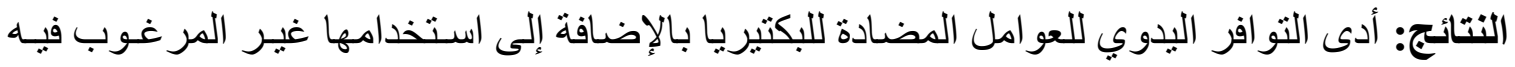

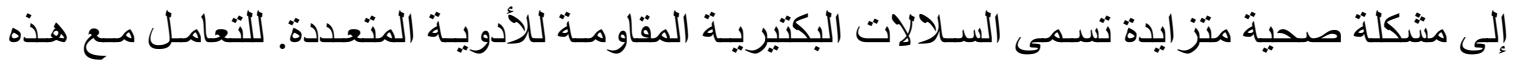

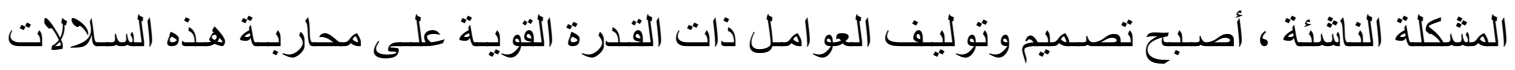
البكتيرية حاجة ملحة.

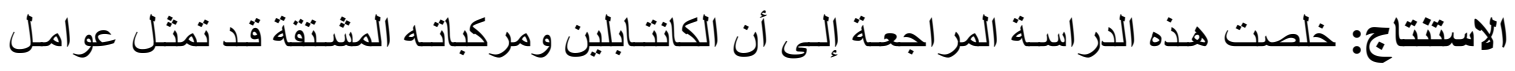

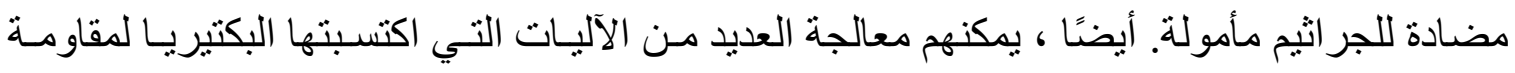
العو امل المضادة للبكتيريا المتوفرة حاليًا.

الكلمات المفتاحية: الكومارين ، البكتيريا المسببة للأمر اض ، الكانتابلين ، النشاط المضاد للبكتيريا.

\section{Introduction}

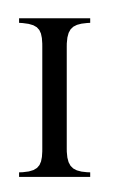

nfections

caused

pathogenic bacteria are the

most frequently observed

type of infectious diseases worldwide. The mortality and morbidity because of bacterial infections are mountingly increasing, and this is considered as one of the most alerting issues ${ }^{1}$. Many Gram-negative (GN) and Gram-positive (GP) infectious bacteria such as Staphylococcus aureus (GP-Sa), Streptococcus pneumonia (GP-Sp), Escherichia coli (GN-Ec), and Pseudomonas aeruginosa (GN-Pa) are accountable for the most documented infectious issues of the hospital and community ${ }^{2}$. Based on WHO data released in 2017, the infection of the highest disease burden is Mycobacterium tuberculosis, which was results in 
approximately 1.8 million deaths every year ${ }^{3}$.

Coumarin-derived products constitute a large family of natural and synthetic compounds that sharing the chemical nucleus made of fused benzene fused with alphapyrone ring ${ }^{4}$. Many compounds holding this chemical moiety in their structures have displayed encouraging biological activities. These potentials involving antitumor 5, antibacterial 6, antifungal 7, anticoagulant ${ }^{8}$, estrogenic 9, vasodilator ${ }^{10}$, sedative 11, analgesic and hypothermic activity ${ }^{12}$, and antiinflammatory ${ }^{13}$ effects.

Derivatives of 7-hydroxy-4-methyl coumarin (Cantabiline, Figure 1) have been of mounting interest in pharmaceutical chemistry, particularly because of their roles as potent antibacterial and antifungal agents ${ }^{14}$.

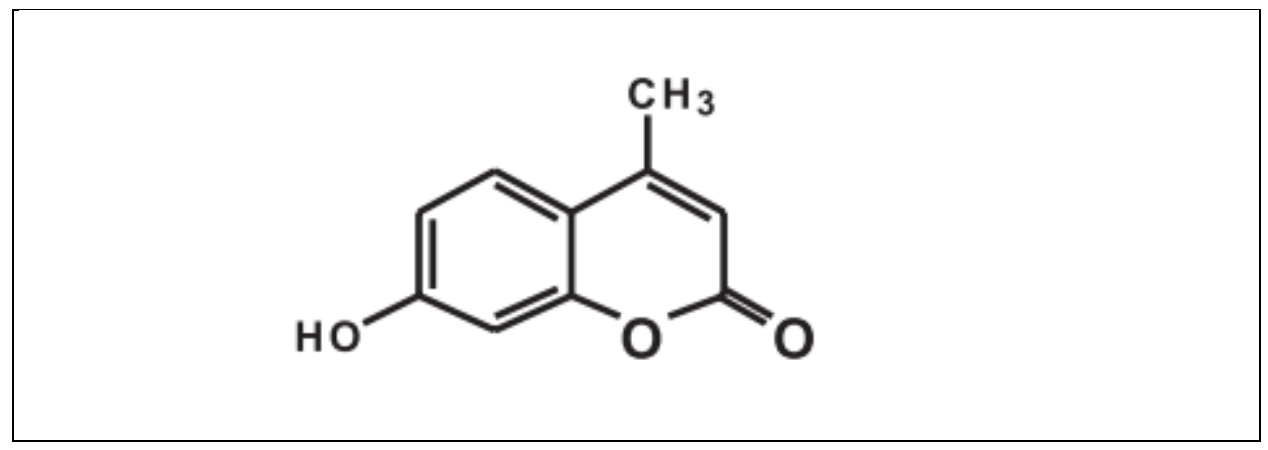

Figure 1: Chemical backbone of 7-hydroxy-4-methyl coumarin (cantabiline).

Sudhir et al have prepared a panel of novel cantabiline derivatives (Scheme 1), herein designated as N1-N7. The authors have investigated the antibacterial activity of these newly synthesized compounds versus four standard bacterial strains; namely Bacillus subtilis, GN-Ec, GN-Pa, and GP$\mathrm{Sa}$. The results of this investigation showed that these cantabiline derivatives exhibited acceptable antibacterial activity versus all the test pathogenic standard bacterial strains. Besides, compound N7 revealed the most potent effect. The authors have concluded that the presence of an azo bond as well as sulfonamide substituents on the cantabiline nucleus may increase the antibacterial potential of these compounds ${ }^{15}$. 


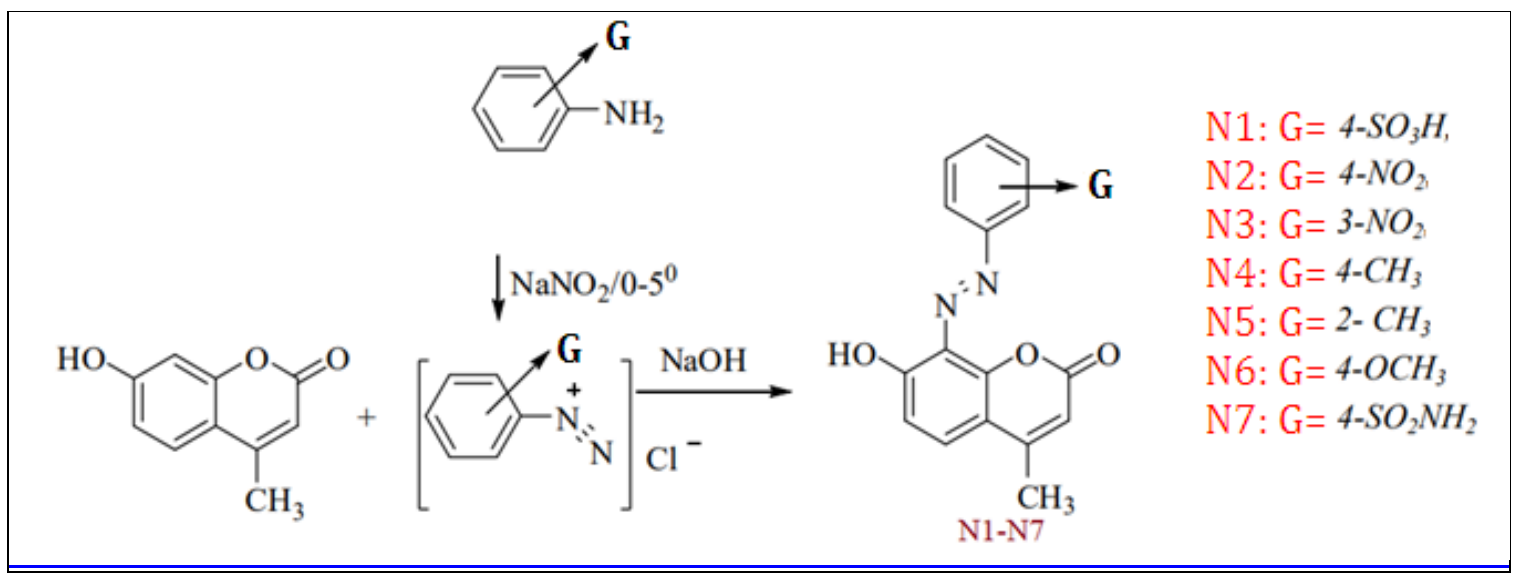

Scheme 1: Synthetic route of N1-N7 compounds as proposed by Sudhir et al.

Hussein et al. have recorded, as displayed in Scheme 2, the design and preparation of seven new Schiff-bases using cantabiline as a precursor. These new derivatives, herein designated as N8-N14, have been examined for their antibacterial activity versus many
GP and GN bacterial strains. The results revealed that these cantabiline derivatives have good activity. Besides, compound N14 exhibited the best potential versus GP-Sa, Micrococcus luteus, and GN-Ec ${ }^{16}$. 


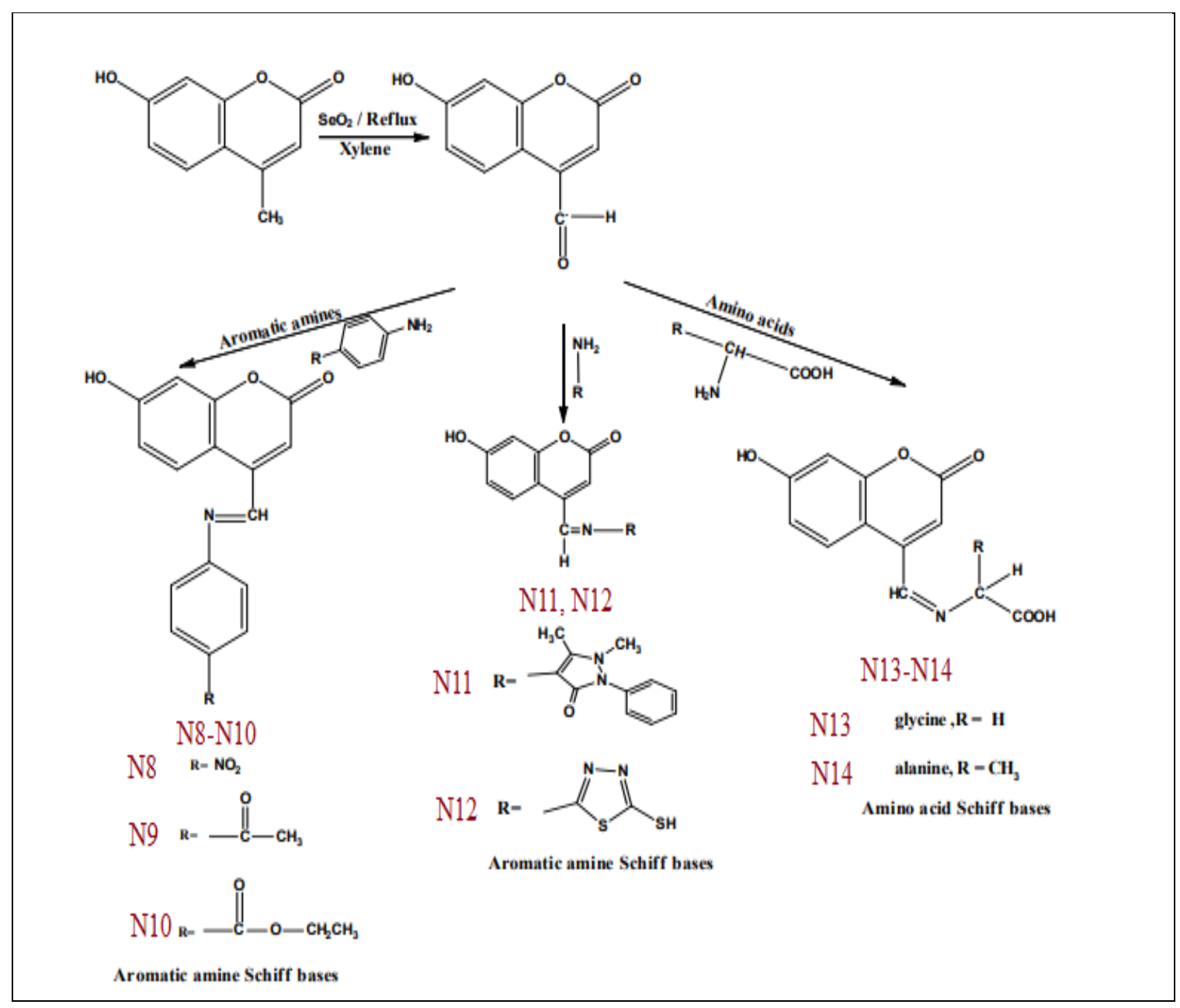

Scheme 2: Synthesis of seven novel cantabiline-Schiff base conjugates as recorded by Hussein et al.

Prabhakara et al. have synthesized a group of metal complexes derived from cantabiline-Schiff base hybridization. These novel complexes, herein designated as N15-N17 (Figure 2), have been evaluated for their antibacterial effect versus two pathogenic standard bacterial strains, including GN-Pa and Proteus mirabilis. The authors revealed that all the newly prepared metal chelates exhibited a hopeful antibacterial activity. The cupper $\left(\mathbf{C u}^{+2}\right)$ complexes showed a more potent effect than those of cobalt $\left(\mathbf{C o}{ }^{+2)}\right.$ and nickel $\left(\mathbf{N i}^{+2)}\right.$ complexes 17 . 


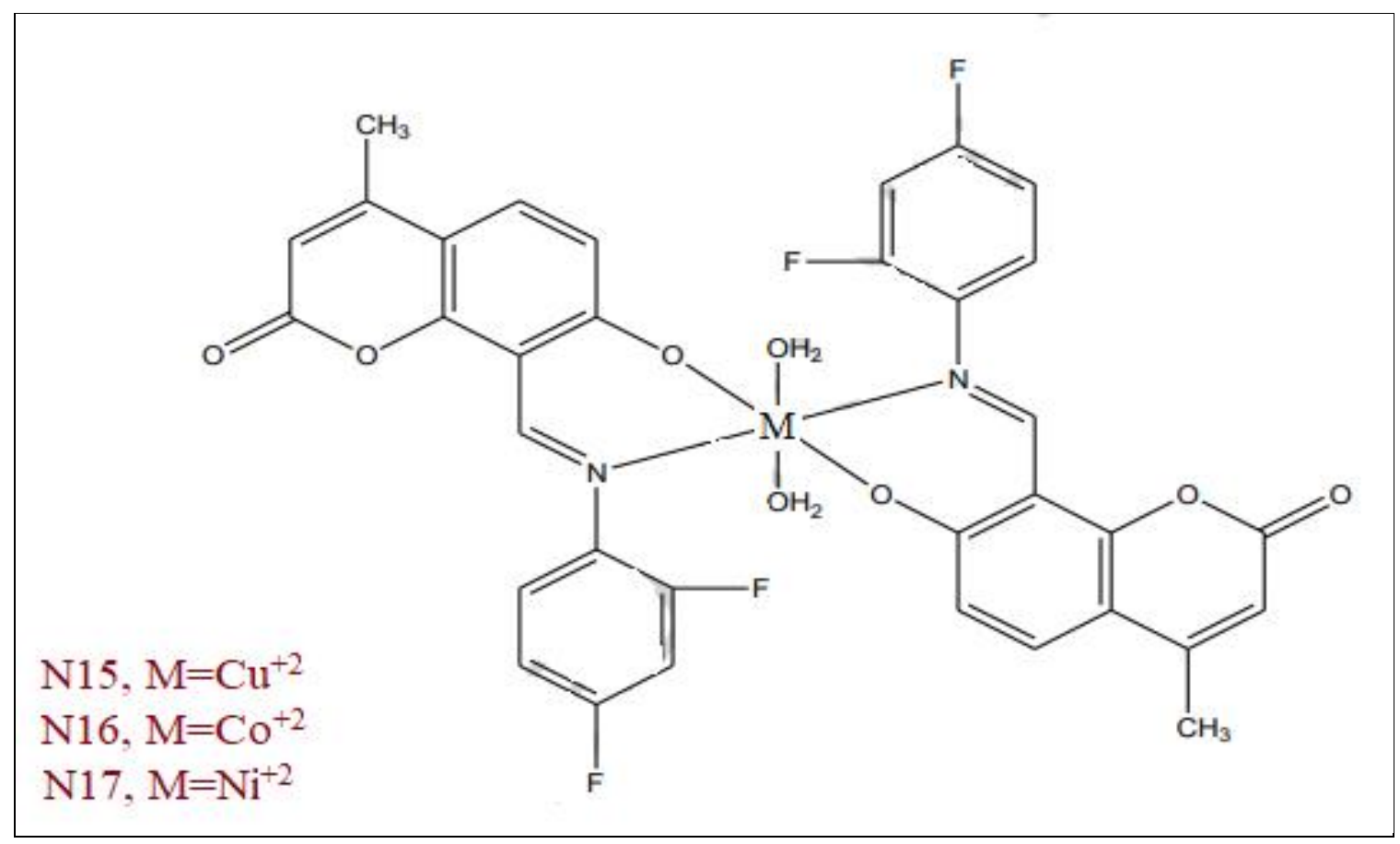

Figure 2: Proposed chemical structure of metal chelates prepared by Prabhakara $e t$ al.

Kraljević et al. have designed and synthesized a panel of 1,2,3triazole-cantabiline conjugates by ecologically-friend technique. The authors have tested the synthesized coumarins for their antibacterial effect versus GP bacteria including GP-Sa, Enterococcus faecalis, Enterococcus faecium resistant to vancomycin, and $\mathrm{GN}$ bacteria including GN-Ec, Acinetobacter baumannii, $\mathrm{GN}-\mathrm{Pa}$, and $\beta$ lactamase-releasing Klebsiella pneumonia. The examined compounds revealed some activity against the test pathogenic bacterial strains. Compound N18 (Figure

2) containing piperazine and morpholine substituents revealed remarkable effect versus many bacterial strains, especially GN-Pa. Compound N19 (Figure 2) that is coupled to butylene revealed a good effect versus methicillinresistant $\mathrm{GP}-\mathrm{Sa}{ }^{18}$. 
<smiles>[R]=CCN1CCN(C(C)=O)CC1COc1ccc2c(C)cc(=O)oc2c1</smiles>

N18<smiles></smiles>

N19

Figure 3: Chemical structures of the synthetic conjugates N18 and N19 that have potent antibacterial activity.

Parmar et al. have recorded the preparation of several cantabilinebased derivatives, as displayed in Scheme 3. These novel derivatives, herein designated as $\mathbf{N 2 0 - N 2 9 ,}$ have been examined for their invitro antibacterial effect versus four standard pathogenic bacterial strains, including; Bacillus subtilis and GP-Sa, GN-Ec, and GN-Pa. The authors revealed that these cantabiline derivatives exhibited a good antibacterial effect against the test bacterial strains. Among these derivatives, compounds $\mathbf{N} 25$ and $\mathbf{N} 27$ were the best ${ }^{19}$. 
<smiles>Oc1cccc(O)c1</smiles><smiles></smiles><smiles>Clc1nc(Cl)nc(Cl)n1</smiles><smiles>Cc1cc(=O)oc2cc(Oc3nc(Cl)nc(NC4CCCCC4)n3)ccc12</smiles><smiles>Cc1cc(=O)oc2cc(Oc3nc(Cl)nc(Cl)n3)ccc12</smiles>

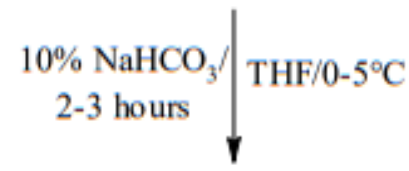<smiles>[R]c1cccc([NH2+])c1</smiles>

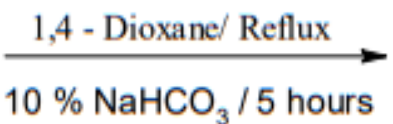<smiles>[R]Cc1ccccc1Nc1nc(NC2CCCCC2)nc(Oc2ccc3c(C)cc(=O)oc3c2)n1</smiles>

Where $\mathrm{R}=$<smiles>Cc1ccc(N)cc1</smiles>

$\mathrm{N} 20$<smiles>Nc1ccc(Cl)cc1</smiles>

$\mathrm{N} 25$<smiles>Nc1ccc(F)cc1</smiles>

N21<smiles>Cc1cccc(N)c1</smiles>

N26<smiles>Nc1ccc(F)c(Cl)c1</smiles>

$\mathrm{N} 22$<smiles>Nc1ccc(N)cc1</smiles>
N27<smiles>Nc1ccc([N+](=O)[O-])cc1</smiles><smiles>COc1ccc(N)cc1</smiles>

N23

N24<smiles>Nc1cccc(Cl)c1</smiles>

N28<smiles>Nc1cccc(Br)c1</smiles>

N29

Scheme 3: Synthetic pathway of the novel cantabiline derivatives as recorded by Parmar et al. 
Tataringa et al. have recorded the synthesis of a panel of compounds using cantabiline as a precursor. These novel derivatives have been examined for their potential as antibacterial products versus many infectious bacterial strains. The researchers revealed that all the newly synthesized derivatives showed high antibacterial activity versus GP-Sa, excellent activity versus Sarcina lutea, and good activity versus GN-Pa. This potential activity could be attributed to the presence of methyl substituent on carbon

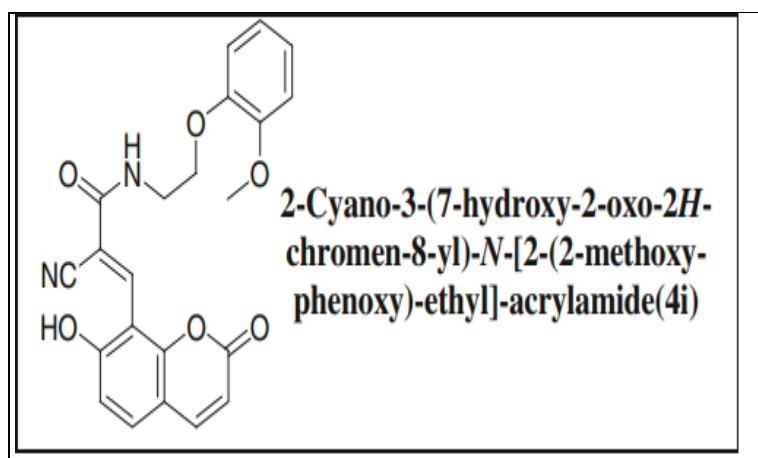

N30

number 4 of the coumarin chemical nucleus ${ }^{20}$.

Darla et al. have recorded a modern technique for the synthesis of twelve 7-hydroxycoumarin derivatives substituted at position 8 from cantabiline as a starting material. These novel cantabiline derivatives have been examined for their antibacterial effect. The authors revealed that two of these new compounds designated as N30 and N31 (Figure 3) exhibited a noticeable antibacterial effect versus GP-Sa, GN-Ec, and GN-Pa 21

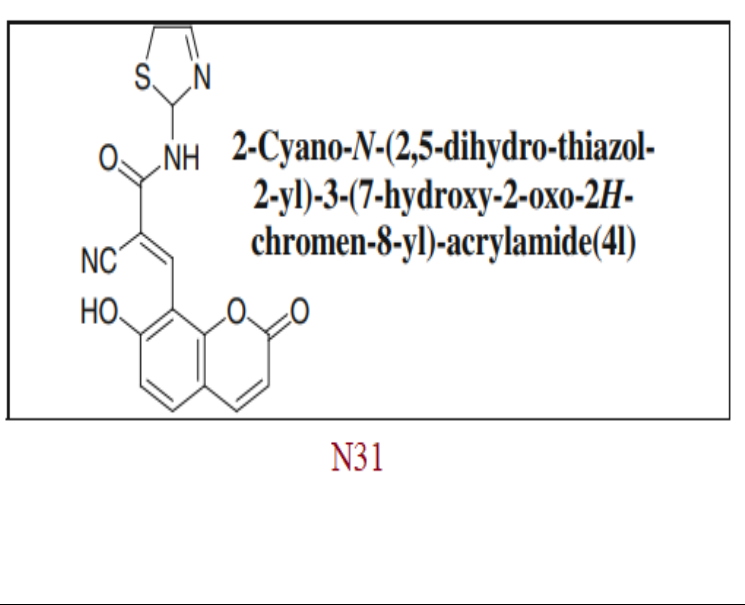

Figure 4: Chemical structures of N30 and N31 compounds

Hosamani et al. have recorded the synthesis of ten cantabilinethiazoline conjugates by applying the microwave irradiation technique, as displayed in Scheme 4. The newly synthesized compounds, herein designated as $\mathbf{N 3 2 - N 4 1 , ~ h a v e ~ b e e n ~ t e s t e d ~ f o r ~}$ their anti-tubercular effect and DNA cleavage. The researchers have revealed that compound N33 showed a high anti-tubercular activity, which may be attributed to the good DNA 


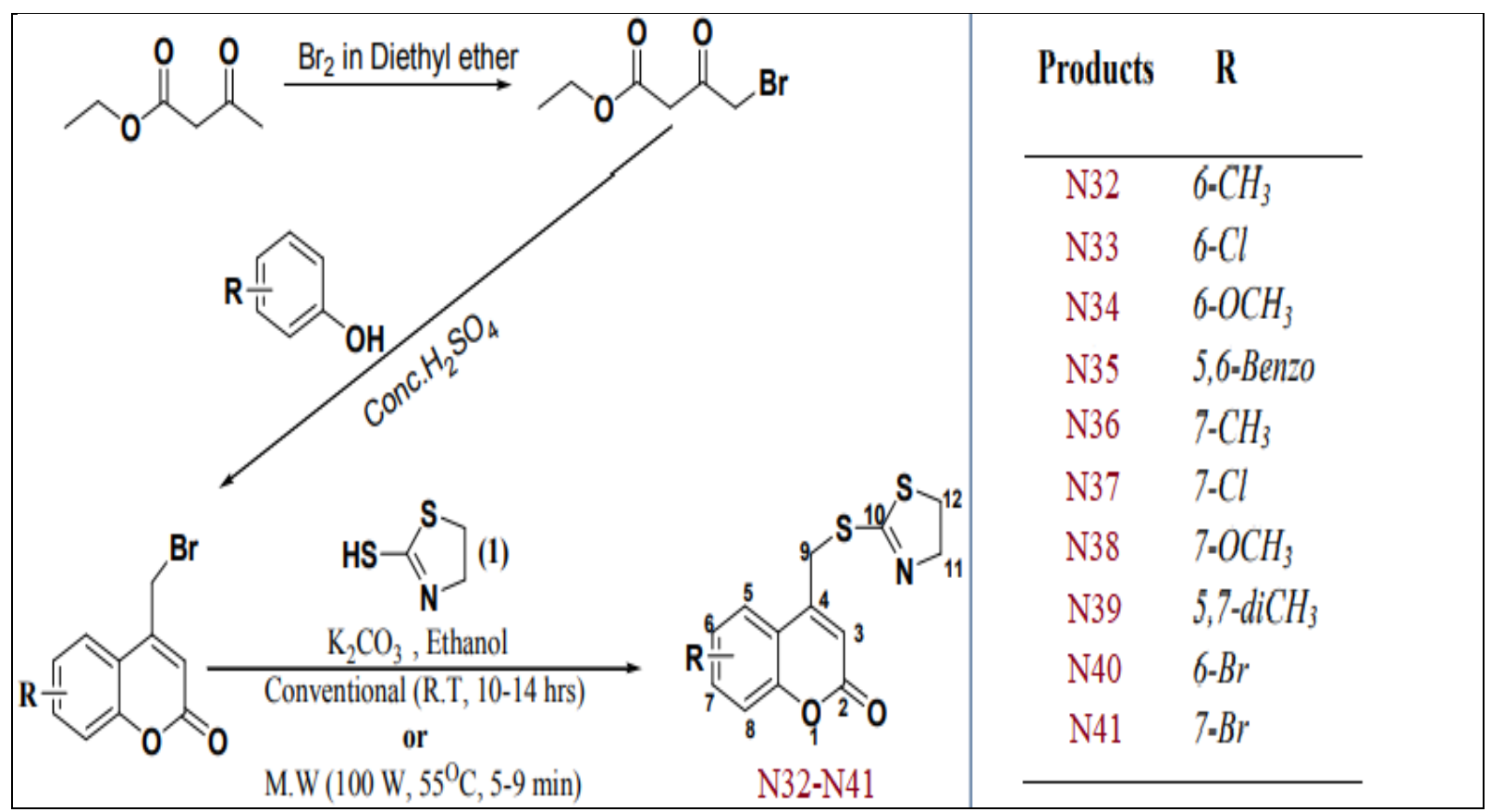

Scheme 4: Synthetic route of N33-N41 conjugates as recorded by Hosamani et al.

cleavage activity exhibited by compound 22. Jogi et al. have recorded the preparation of six new cantabiline-based azo compounds, as displayed in Figure 4. These novel compounds, herein designated as $\mathbf{N 4 2 - N 4 7 , ~ h a v e ~ b e e n ~}$ tested for their potential as effective antibacterial products against certain pathogenic standard bacteria. The results showed that these cantabiline-based azo compounds exhibited an antibacterial activity similar to those of streptomycin and ampicillin ${ }^{23}$. 


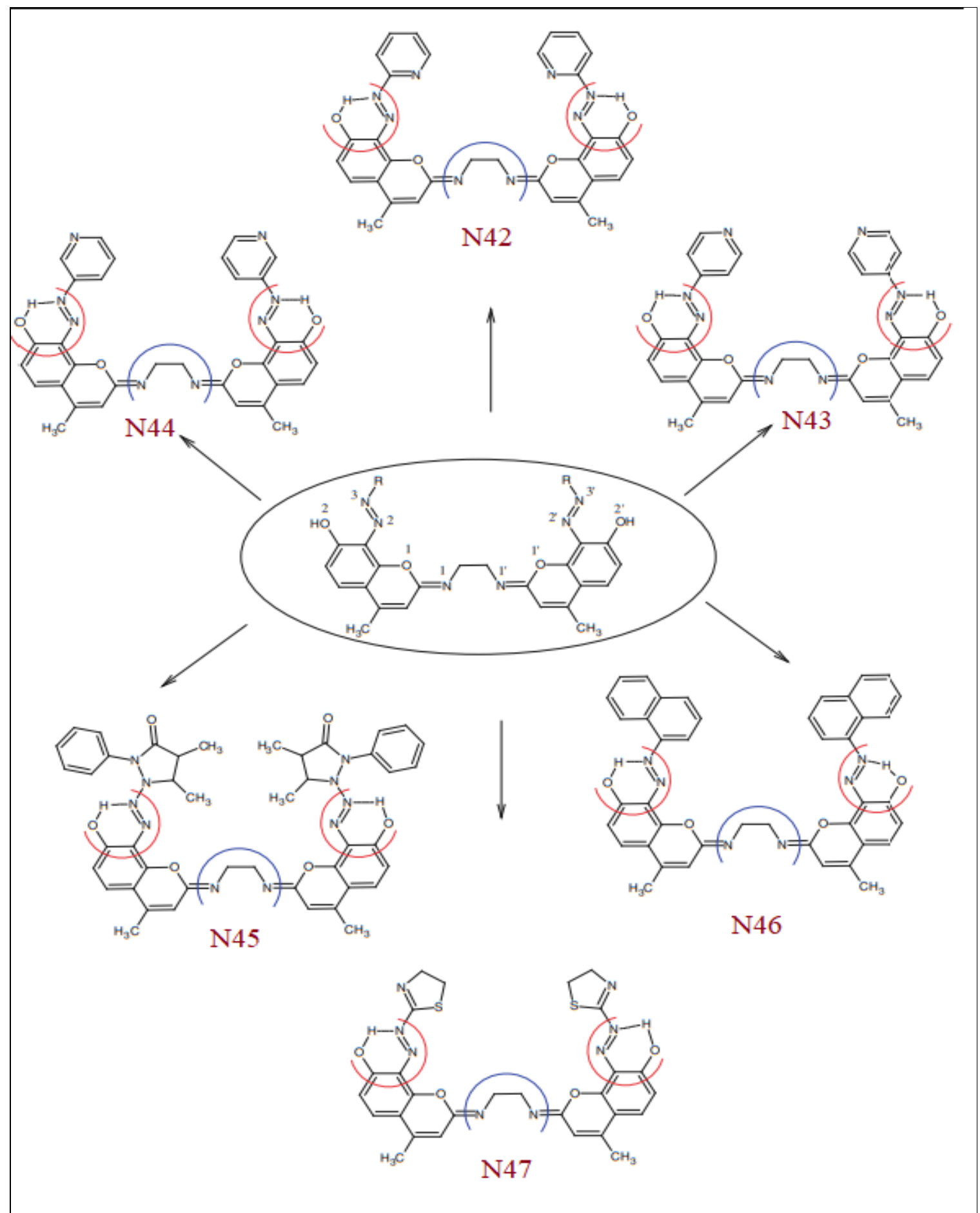

Figure 5: The chemical structures of cantabiline-based azo compounds as depicted by Jogi et al.

A panel of cantabiline-based Schiff bases was synthesized by Lamani et al. by the condensation of 8formyl-cantabiline with 3-methyl- 
5-oxo-1,2,4-triazoles, as displayed in Scheme 5. These new condensates, herein designated as N48-N55, have been examined for their antibacterial activity versus Bacillus subtilis and GNEc. The authors revealed that these compounds showed promising antibacterial effect versus the test pathogenic
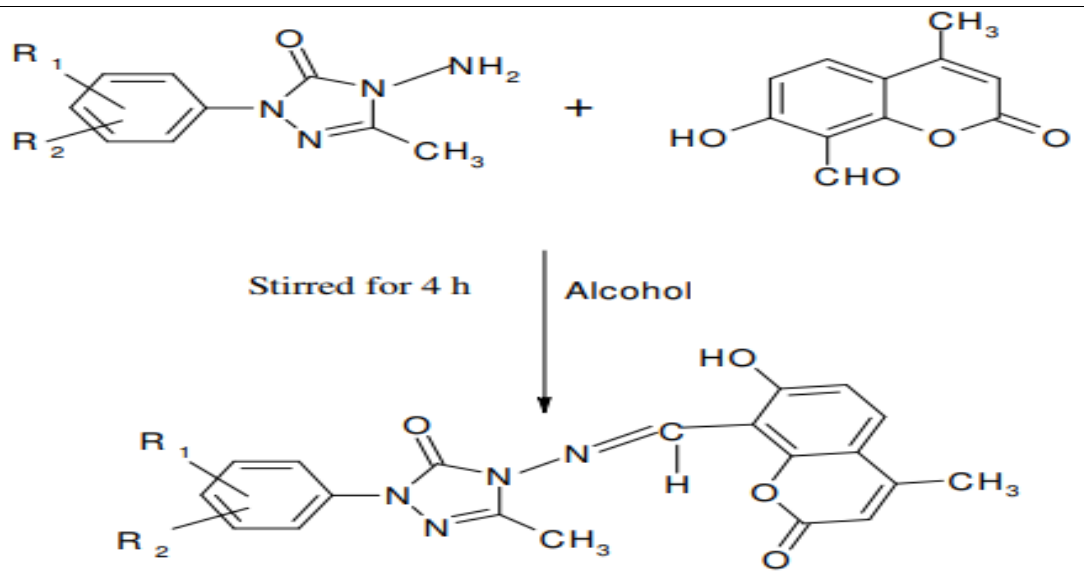

\begin{tabular}{|c|c|c|}
\hline Compd & R1 & R2 \\
\hline N48 & $\mathbf{H}$ & $\mathbf{H}$ \\
\hline N49 & $m-\mathrm{Cl}$ & $\mathbf{H}$ \\
\hline N50 & $P-\mathrm{C} 1$ & $\mathbf{H}$ \\
\hline N5 1 & $\mathrm{P}-\mathrm{OCH}_{3}$ & $\mathbf{H}$ \\
\hline N52 & $\boldsymbol{P}-\mathrm{CH}_{3}$ & $\mathbf{H}$ \\
\hline N53 & $P-\mathrm{COOH}$ & $\mathbf{H}$ \\
\hline N54 & 3-C1 & 4- $\mathrm{CH}_{3}$ \\
\hline N55 & $3-\mathrm{NO}_{2}$ & 4-C1 \\
\hline
\end{tabular}

Scheme 5: The preparation of cantabiline-based Schiff bases as recorded by Lamani et al.

Zayane et al. have designed and several novels cantabiline-based derivatives, as displayed in Scheme 6 and 7. The researchers also have been examined the antibacterial activity of these new derivatives, herein designated as N56-N64, versus many pathogenic microbial strains such as Pseudomonas huttiensis,
Pseudomonas savatanoi, and Agrobacterium tumefasciens. The results revealed that these cantabiline-based derivatives displayed an acceptable antibacterial effect versus Pseudomonas savatanoi. Besides, compounds $\mathbf{N 5 7}$ and N60 were the most active against this bacterial strain. The results have also 
displayed that only the substitution of the aromatic system derivatives N62, N63, of cantabiline at para-position with and N64 were active versus dimethylamine functional group Pseudomonas huttiensis. The could be the reason behind this authors concluded that the improved antibacterial activity ${ }^{25}$.

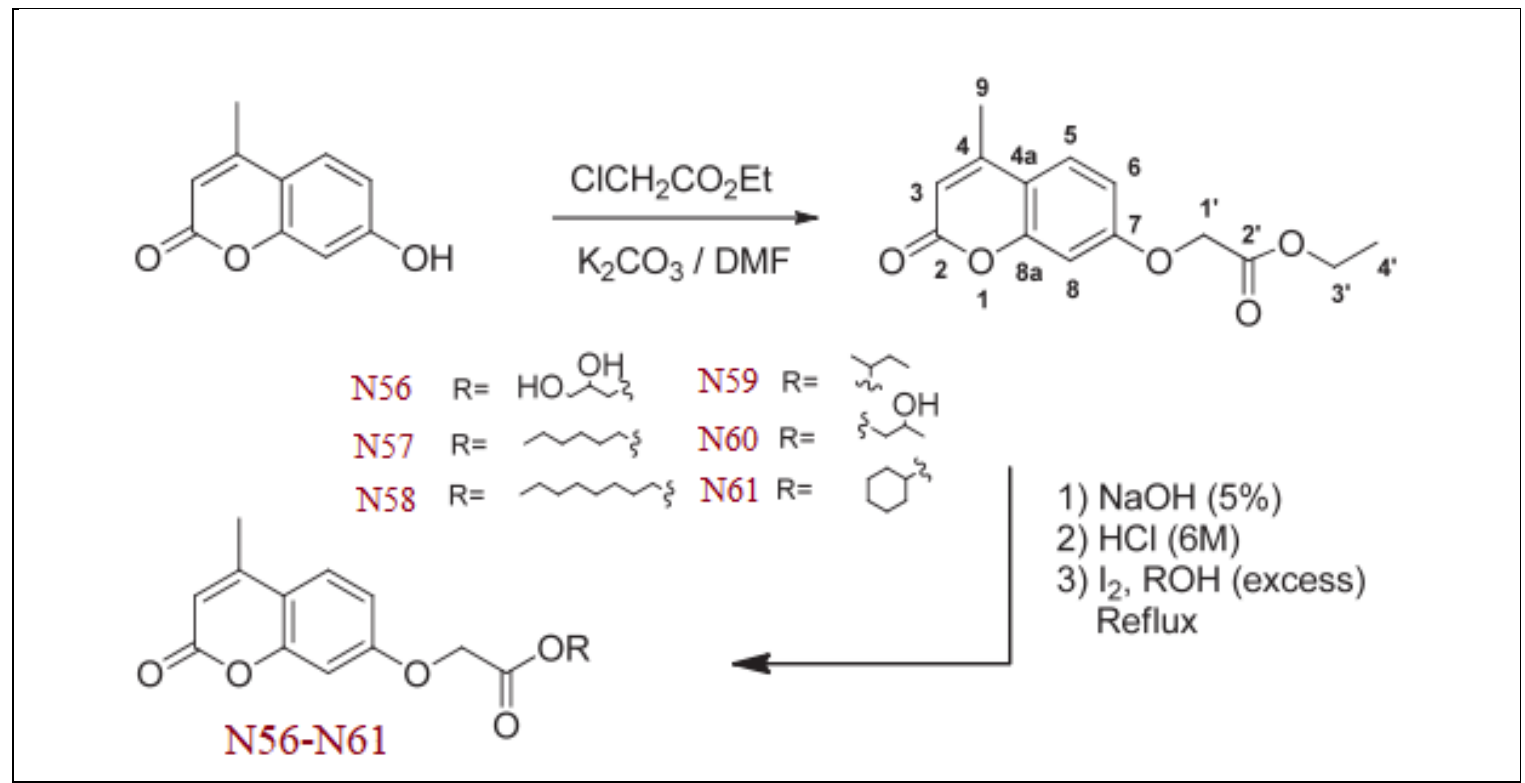

Scheme 6: Synthetic route of N56-N61 compounds as reported by Zayane et al.<smiles>CCOC(=O)COc1ccc2c(C)cc(=O)oc2c1</smiles>

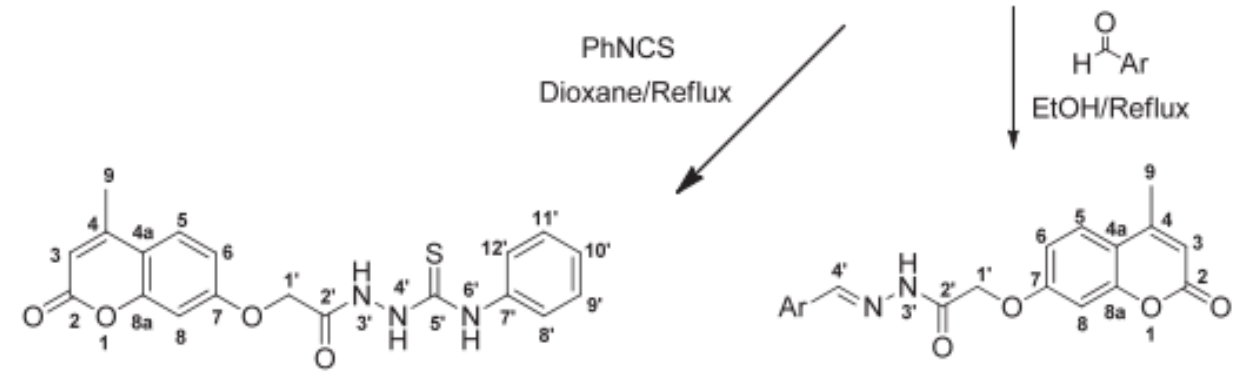

N62-N64

$\mathrm{N} 62 \cdot \mathrm{Ar}=p-\mathrm{N}(\mathrm{Me})_{2} \mathrm{C}_{6} \mathrm{H}_{4}$

$\mathrm{N} 63 \mathrm{Ar}=3,4-\mathrm{di}(\mathrm{MeO}) \mathrm{C}_{6} \mathrm{H}_{3}$

$\mathrm{N} 64 \mathrm{Ar}=p-\mathrm{tBuC}_{6} \mathrm{H}_{4}$

Scheme 7: Synthetic route of N62-N64 compounds as reported by Zayane et al. 
Gubta et al. have recorded the preparation of six new cantabiline derivatives designated as N65N70. These novel coumarin derivatives (Figure 5) have been tested for their antibacterial effect versus two pathogenic standard bacterial strains, namely Bacillus subtilis and GN-Ec. The results displayed that all the synthesized derivatives exhibited improved antibacterial activity in comparison with ampicillin.

Also, compound $\mathbf{N 6 5}$ showed the highest activity versus the test bacterial strains ${ }^{26}$.

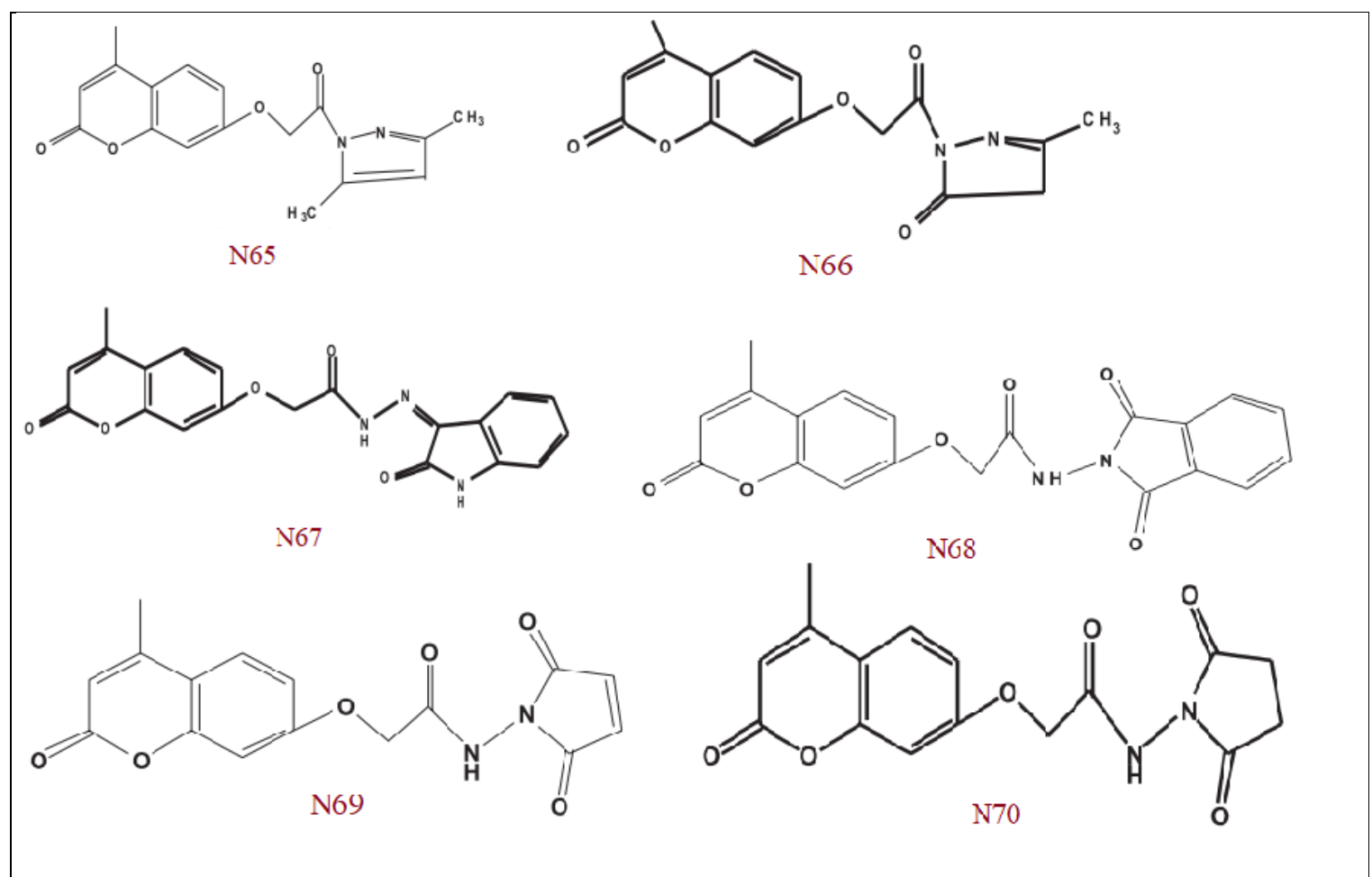

Figure 6: The chemical structures of the novel compounds prepared by Gubta et al.

A panel of cantabiline-based isoxazoline compounds was synthesized by Suresh et al. These newly synthesized compounds, herein designated as N71-N78 (as displayed in Figure 6), have been tested for their antibacterial activity versus two pathogenic bacterial strains, including $G N$ -
$E c$ and $G P-S a$. The results have displayed that these novel coumarin derivatives exhibited a good antibacterial effect versus the test bacterial strains. The researchers concluded that the substitution with an electronwithdrawing functional group could improve the potential of 
antibacterial these cantabiline- potent antibacterial products ${ }^{27}$. based isoxazoline compounds as

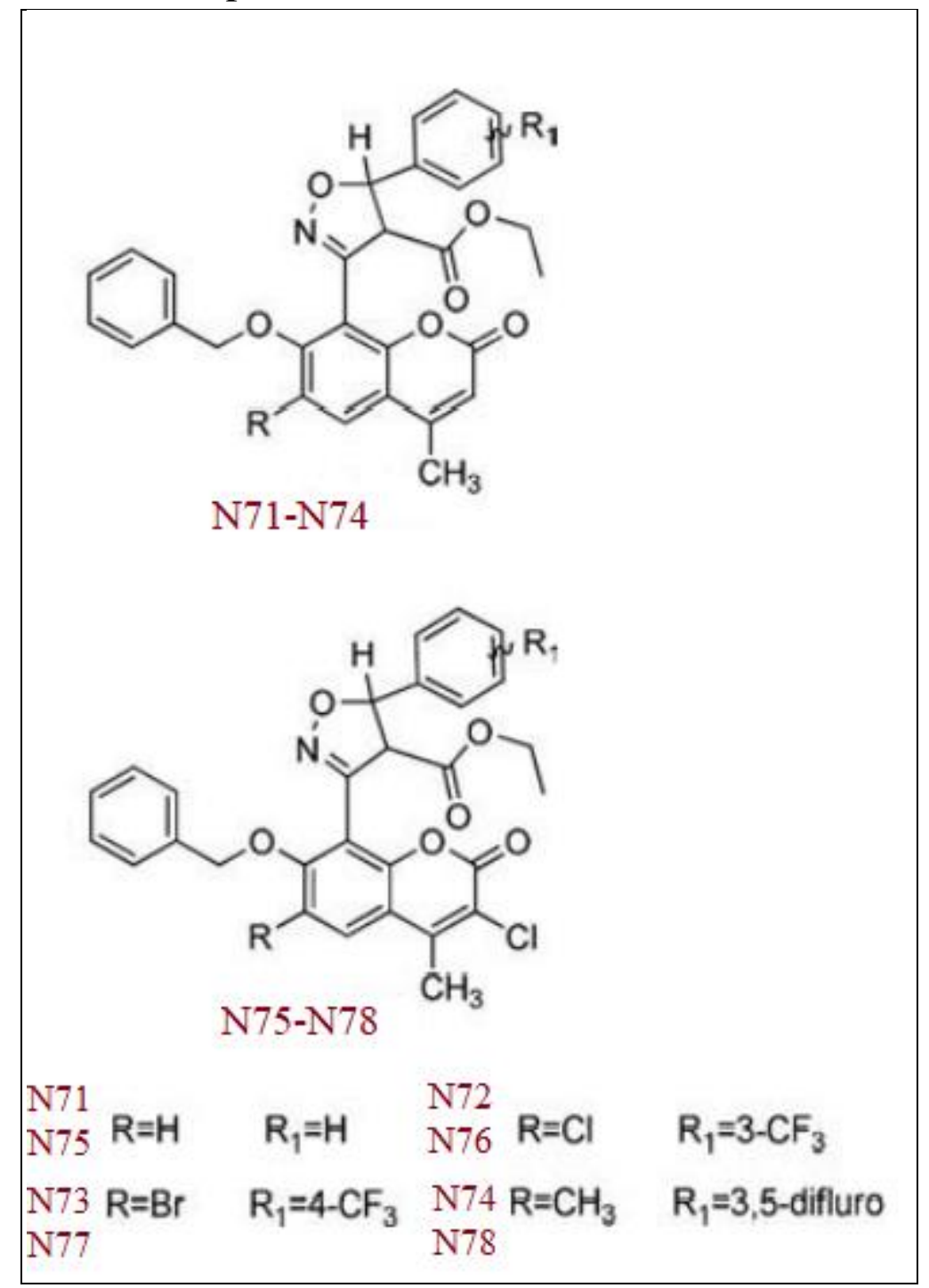

Figure 7: Chemical structures of the cantabiline-based isoxazoline compounds prepared by Suresh $e t$ al.

Alghool has synthesized many metal $(\mathrm{Ni}, \mathrm{Cu}, \mathrm{Co}, \mathrm{Cd}$, and $\mathrm{Zn})$ complexes from cantabiline-amine ligand. These complexes have been evaluated for their antibacterial activity versus two GP bacterial strains; namely GP-Sa and Bacillus subtilis, and two GN bacterial strains including GN-Ec and GN-Pa. The researchers revealed that the resulted complexes have higher antibacterial activity in comparison 
to those of cantabiline-amine ligand and norfloxacin ${ }^{28}$.

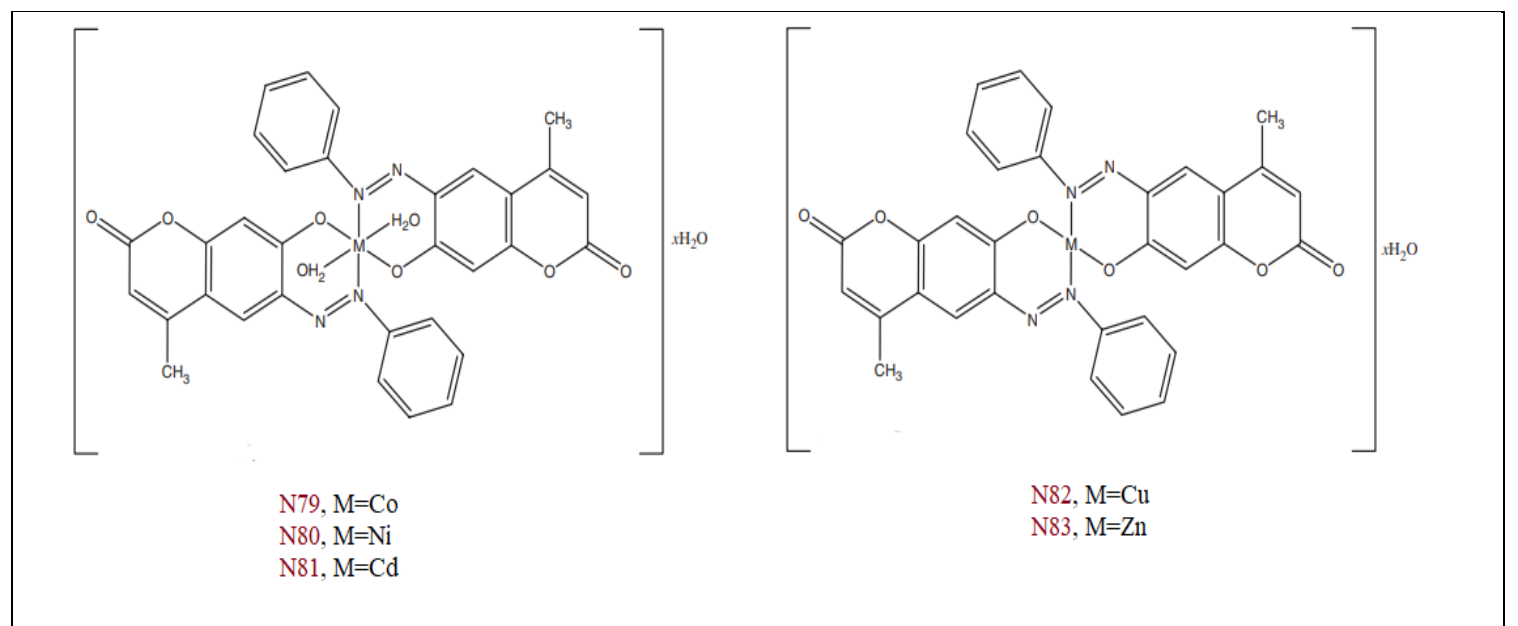

Figure 8: Chemical structures of the metal complexes prepared by Alghool.

Gopi C et al. have prepared many cantabiline-based compounds by interacting cantabiline with aromatic hydrocarbon. The synthetic route is displayed in Scheme 8 . The newly synthesized compounds have been subjected to the antibacterial evaluation versus three pathogenic bacterial strains, including GN-Pa, Bacillus subtilis, and GN-Ec. The results displayed that these derivatives exhibited enhanced antibacterial effect versus the test bacterial strains in comparison to the antibiotic ampicillin. The authors concluded that the insertion of the electronreleasing group such as propyl, ethyl methyl, hydroxyl, and the azo-functional group might be responsible for this improved antibacterial potential ${ }^{29}$. 


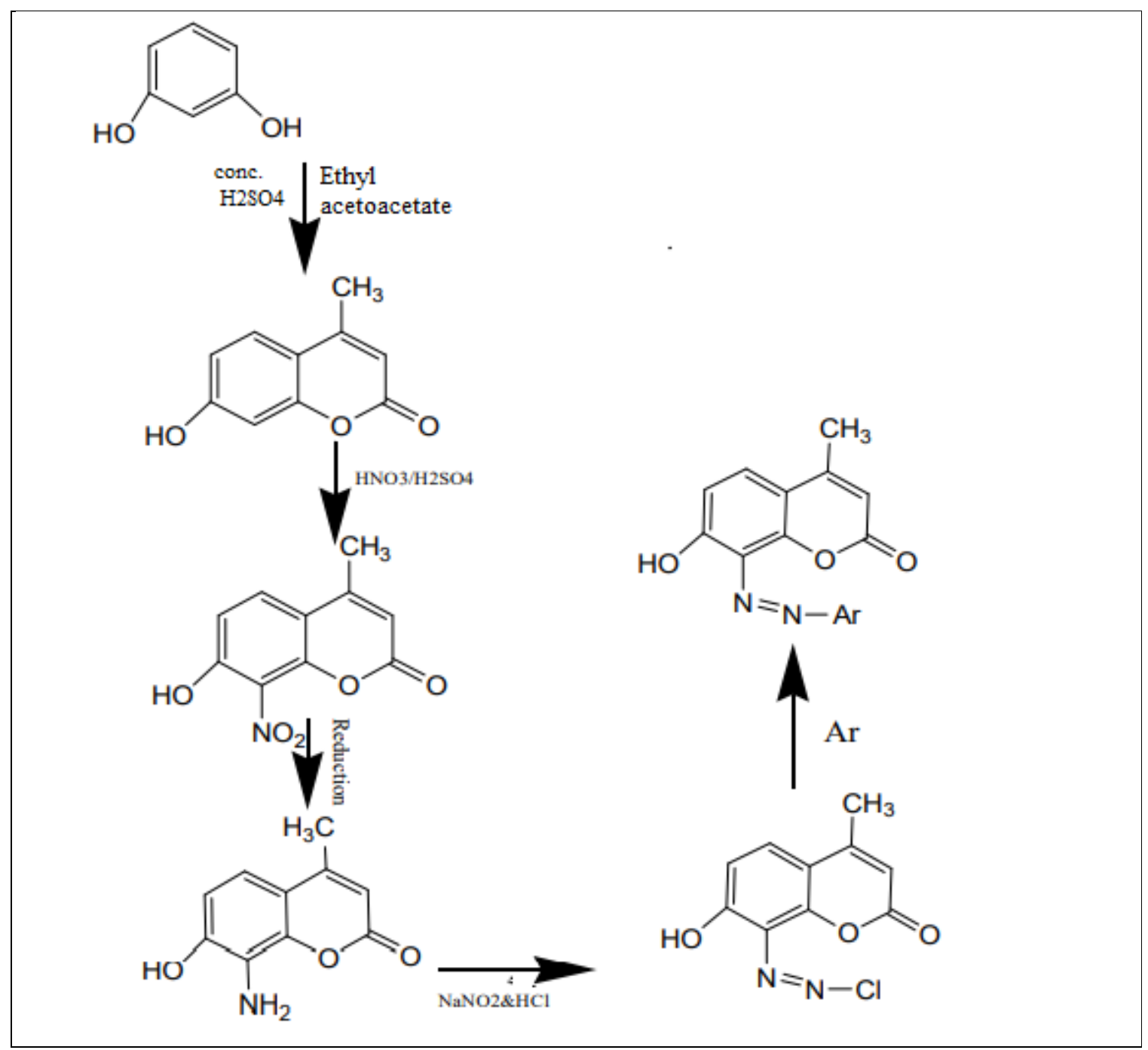

Scheme 8: The synthetic route of the cantabiline-based compounds prepared by Gopi Cet al.

\section{Conclusion}

This review study has concluded that cantabiline and its derived compounds may represent hopeful antibacterial agents. Also, they can address several mechanisms acquired by bacteria for resisting the currently-available antibacterial agents. 


\section{References}

1- X.-M. Peng, G. L.V. Damu, and C.- He Zhou, "Current developments of coumarin compounds in medicinal chemistry," Curr. Pharm. Des., vol. 19, no. 21, pp. 3884-3930, 2013, doi: $10.2174 / 1381612811319210$ 013.

2- B. Zhang, "Comprehensive review on the anti-bacterial activity of 1,2,3-triazole hybrids," Eur. J. Med. Chem., pp. 1-39, 2019, doi: 10.1016/j.ejmech.2019.02.05 5.

3- J. Zhang, Y. Ba, S. Wang, H. Yang, $\mathrm{X}$. Hou, and $\mathrm{Z}$. $\mathrm{Xu}$, "Nitroimidazole-containing compounds and their antibacterial and antitubercular activities," Eur. J. Med. Chem., vol. 179, pp. 376-388, 2019, doi: 10.1016/j.ejmech.2019.06.06 8.

4- $\quad$ Y. F. Mustafa, M. K. Bashir, and M. K. Oglah, "Original and innovative advances in the synthetic schemes of coumarin-based derivatives: A review," Syst. Rev. Pharm., vol. 11, no. 6, pp. 598-612, 2020, doi: 10.31838/srp.2020.6.90.
5- M. K. Bashir, Y. F. Mustafa, and M. K. Oglah, "Synthesis and antitumor activity of new multifunctional coumarins," Period. Tche Quim., vol. 17, no. 36, pp. 871-883, 2020.

6- Y. F. Mustafa, "Synthesis, characterization and antibacterial activity of novel heterocycle, coumacine, and two of its derivatives," Saudi Pharm. J., vol. 26, no. 6, pp. 870-875, 2018, doi: 10.1016/j.jsps.2018.03.010.

7- $\quad$ Y. F. Mustafa, R. R. Khalil, and E. T. Mohammed, "Antimicrobial activity of aqueous extracts acquired from the seeds of two apples' cultivars," Syst. Rev. Pharm., vol. 11, no. 2, pp. 382-387, 2020 , doi: 10.5530/srp.2020.2.56.

8- Y. F. Mustafa, "Synthesis of new coumarin derivatives with suspected anticoagulant activity," Iraqi J. Pharm., vol. 12, no. 1, pp. 20-32, 2011 , doi: 10.33899/iphr.2012.62340.

9- M. Musa, J. Cooperwood, and M. O. Khan, A Review of Coumarin Derivatives in Pharmacotherapy of Breast Cancer, vol. 15, no. 26. 2008.

10- H. Ahn, M. Weaver, D. 
Lyon, R. Eunyoung Choi, and R. B. Fillingim, "CarrierMediated Prodrug Uptake to Improve the Oral Bioavailability of Polar Drugs: An Application to an Oseltamivir Analogue," J Pharm Sci, vol. 176, no. 10, pp. 139-148, 2017, doi: 10.1016/j.physbeh.2017.03.0 40.

11- G. Bansuri, J. Limbasiya, and M. Nandasana, "Bioactivity of 7-Hydroxy 4Methyl Coumarin," Int. J. Curr. Microbiol. Appl. Sci. ISSN, vol. 8, no. 04, pp. 2737-2741, 2019, doi: https://doi.org/10.20546/ijcm as.2019.804.318.

12- K. P. Barot, S. V. Jain, L. Kremer, S. Singh, and M. D. Ghate, "Recent advances and therapeutic journey of coumarins: Current status and perspectives," Med Chem Res, vol. 24, no. 7. pp. 2771-2798, 2015, doi: 10.1007/s00044-015-1350-8.

13- D. Srikrishna, C. Godugu, and P. K. Dubey, "A review on pharmacological properties of coumarins," Mini-Reviews Med. Chem., vol. 18, no. 2, 2016, doi: $10.2174 / 1389557516666160$ 801094919 .
14- Y. F. Mustafa and N. T. Abdulaziz, "Biological potentials of hymecromonebased derivatives: A systematic review," Syst. Rev. Pharm., vol. 11, no. 11, pp. 438-452, 2020, doi: 10.31838/srp.2020.11.65.

15- P. Sudhir Kumar and J. Sahoo, "Evaluation of invitro antimicrobial activity of some newly synthesized 7hydroxy 4-methyl coumarin congeners," Der Pharm. Lett., vol. 7, no. 2, pp. 60-64, 2015.

16- D. M. Hussein, S. B. AlJuboory, and A. A. Razzak Mahmood Kubba, "Synthesis, characterization and antibacterial evaluation with computational study of new Schiff bases derived from 7-hydroxy-4-methyl coumarin," Orient. J. Chem., vol. 33, no. 2, pp. 768-782, 2017 , doi: $10.13005 / \mathrm{ojc} / 330224$.

17- C. T. Prabhakara, S. A. Patil, S. S. Toragalmath, S. M. Kinnal, and P. S. Badami, "Synthesis, characterization and biological approach of metal chelates of some first row transition metal ions with halogenated bidentate coumarin Schiff bases containing $\mathrm{N}$ and $\mathrm{O}$ donor 
atoms," J. Photochem. Photobiol. B Biol., vol. 157, pp. 1-14, 2016, doi: 10.1016/j.jphotobiol.2016.02 .004 .

18- T. G. Kraljević, A. Harej, M. Sedić, and S. K. Pavelić, "SC," Eur. J. Med. Chem., 2016 , doi: 10.1016/j.ejmech.2016.08.06 2.

19- K. A. Parmar, C. R. Patel, S. A. Joshi, and R. I. Patel, "Synthesis, characterization and antibacterial activity of 2-(4-methyl -7-hydroxycoumarin)-4-

(cyclohexylamino)-6(arylamino)-s-triazine," Der Pharm. Lett., vol. 5, no. 1, pp. 24-27, 2013.

20- G. Tataringa and A. Maria Zbancioc, "Coumarin Derivatives with Antimicrobial and Antioxidant Activities," in Phytochemicals in Human Health, 2020, pp. 1-19.

21- M. M. Darla, B. S. Krishna, K. Umamaheswara Rao, N. B. Reddy, M. K. Srivash, K. Adeppa, C. S. Sundar, C. S. Reddy, and K. Misra, "Synthesis and bioevaluation of novel 7hydroxy coumarin derivatives via Knoevenagel reaction," Res. Chem. Intermed., vol. 41, no. 2, pp. 1115-1133, 2015, doi: 10.1007/s11164-013-1258-1.

22- R. S. Keri, K. M. Hosamani, R. V. Shingalapur, and M. H. Hugar, "Analgesic, antipyretic and DNA cleavage studies of novel pyrimidine derivatives of coumarin moiety," Eur. J. Med. Chem., vol. 45, no. 6, pp. 25972605, 2010, doi: 10.1016/j.ejmech.2010.02.04 8.

23- P. S. Jogi, J. Meshram, J. Sheikh, and T. Ben Hadda, "Synthesis, biopharmaceutical characterization, and antimicrobial study of novel azo dyes of 7-hydroxy-4methylcoumarin," $\quad \mathrm{Med}$. Chem. Res., vol. 22, no. 9, pp. 4202-4210, 2013, doi: 10.1007/s00044-012-0421-3.

24- K. S. S. Lamani, O. Kotresh, M. A. Phaniband, and J. C. Kadakol, "Synthesis, characterization and antimicrobial properties of schiff bases derived from condensation of 8-formyl-7hydroxy-4-methylcoumarin and substituted triazole derivatives," E-Journal Chem., vol. 6, no. SUPPL. 1, 
pp. 239-247, 2009, doi: $10.1155 / 2009 / 787150$.

25- M. Zayane, A. Romdhane, M. Daami-Remadi, and $\mathrm{H}$. Ben Jannet, "Access to new antimicrobial $4-$ methylumbelliferone derivatives," J. Chem. Sci., vol. 127, no. 9, pp. 16191626, 2015, doi: 10.1007/s12039-015-0927-6.

26- M. Gupta, S. Kumar, and M. K. Gupta, "Synthesis and antimicrobial activity of some novel derivatives of 7 hydroxy-4- methyl coumarin," Int. J. Pharm. Sci., vol. 1, no. 1, pp. 19-26, 2015.

27- G. Suresh, R. Venkata Nadh, N. Srinivasu, and K. Kaushal, "Novel coumarin isoxazoline derivatives: Synthesis and study of antibacterial activities," Synth. Commun., vol. 46, no. 24, pp. 1972-1980, 2016, doi:

10.1080/00397911.2016.124 2748 .

28- S. Alghool, "Metal complexes of azo coumarin derivative: Synthesis, spectroscopic, thermal, and antimicrobial studies," $J$. Coord. Chem., vol. 63, no. 18, pp. 3322-3333, 2010, doi:

10.1080/00958972.2010.508 519.

29- C. Gopi and M. D. Dhanaraju, "Synthesis , characterization and antimicrobial action of novel azo dye derivied from 4-Methyl7-OH-8-Nitro coumarin," $J$. Pharm. Res., vol. 4, no. 4, pp. 7-9, 2011. 